\title{
IMPLEMENTASI FUNGSI PERATURAN WALIKOTA NO.79 TAHUN 2010 TENTANG PEMBATASAN USAHA WARALABA MINIMARKET DI KOTA YOGYAKARTA (STUDI KEBERADAAN USAHA INDOMART DAN ALFAMART DI DAERAH ISTIMEWA YOGYAKARTA)
}

\author{
Ulfaroffilah Meiyona ${ }^{l}$ \\ (Universitas Muhammadiyah Riau, Indonesia,ulfaroffilah@gmail.com) \\ Hilyatul Asfia ${ }^{2}$ \\ (Institut Agama Islam Negeri Palangka Raya, Indonesia, hilyatulasfia1 @ gmail.com \\ Qisthi Karami ${ }^{3}$ \\ (Universitas Islam Indonesia, Indonesia, qisthikarami@gmail.com)
}

\begin{abstract}
This study aims to determine the implementation of Perwal No. 79 of 2010 on the existence of networked Indomaret and Alfamart businesses in Yogyakarta and the attitude of the government and to find an ideal design or form of arrangement related to the existence of the networked Indomaret and Alfamart franchise businesses. This research is a type of normative-empirical law research regarding the implementation of normative legal provisions in their actions in every legal event. The results of this study are based on the urgency of the problem based on several factors related to the law enforcement process in Perwal No. 79 of 2010 on the existence of networked Indomaret and Alfamart businesses in Yogyakarta. The arrangement in the substance has actually implemented the accommodation of the number of minimarket franchises as many as 52 units. the fact is that in the field there are more than 52 franchise units. Regarding the existence of minimarket franchises, it is only limited to traditional markets which are at least 400 meters away, but there are no restrictions related to the existence of local MSMEs. The conclusion of this study is that the implementation of the Yogyakarta Mayor's Regulation Number 79 of 2010 concerning the limitation of minimarket franchise businesses in the city of Yogyakarta has not gone well, the existing rules for the franchise business itself are based on the rules as many as 52 units, while in practice there are more than 52 franchise units.
\end{abstract}

Keywords : Regulation, franchise system, and small and medium enterprises (SMEs).

\begin{abstract}
Abstrak
Penelitian ini bertujuan untuk mengetahui impelementasi dari Perwal Nomor 79 Tahun 2010 terhadap keberadaan usaha Indomaret dan Alfamart berjaring di Yogyakarta serta sikap pemerintah dan Menemukan desain atau bentuk pengaturan yang ideal terkait keberadaan usaha Indomaret dan Alfamart waralaba berjaring tersebut. Penelitian ini merupakan penelitian jenis Hukum Normatif-Empiris mengenai implementasi ketentuan hukum normatif dalam aksinya pada setiap persitiwa hukum. Hasil dari penelitian ini Berbagai urgensi permasalahan berdasar pada Beberapa faktor terkait proses penegakan hukum dalam Perwal Nomor 79 Tahun 2010 terhadap keberadaan usaha Indomaret dan Alfamart berjaring di Yogyakarta. Pengaturan dalam substansi tersebut sejatinya telah menerapkan pengakomodiran jumlah keberadan waralaba minimarket sebanyak 52 unit. faktanya dilapangan keberadaan waralaba lebih dari 52 unit.Berkaitan dengan keberadaan waralaba minimarket hanya dibatasi dengan pasar tradisional yang jaraknya minimal 400 meter, namun tidak ada pembatasan berkaitan dengan keberadaan UMKM
\end{abstract}


setempat. Kesimpulan dari penelitian ini adalah Implementasi Peraturan Walikota Yogyakarta Nomor 79 Tahun 2010 tentang pembatasan usaha waralaba minimarket di Kota Yogyakarta belum berjalan dengan baik, aturan yang ada untuk usaha waralaba sendiri berdasarkan aturan sebanyak 52 unit, sementara pada prakteknya lebih dari 52 unit waralaba.

Kata Kunci : Regulasi, sistem waralaba, dan usaha kecil menengah (UKM).

\section{Pendahuluan}

Dewasa ini perkembangan globalisasi ekonomi berkembang secara pesat, sistem usaha waralaba menjadi salah satu terobosan dalam perdagangan yang sangat menjanjikan. Waralaba adalah hak khusus yang dimiliki oleh orang perseorangan atau badan usaha terhadap system bisnis dengan ciri khas usaha dalam rangka memasarkan barang dan / atau jasa yang telah terbukti berhasil dan dapat dimanfaatkan ${ }^{1}$. Usaha waralaba telah memebuktikan dirinya sebagai bentuk usaha yang menjanjikan dengan peningkatan yang sangat pesat hal tersebut menjadi daya tarik investor untuk berinvestasi dengan tingkat kegagalan yang rendah. Bisnis waralaba memiliki beberapa keunggulan, yaitu dapat memperluas jaringan usaha dengan cepat, menciptakan kemitraan yang saling menguntungkan, meningkatkan lapangan kerja baru, mampu mempercepat alih teknologi dan meningkatkan peluang berusaha bagi Usaha Mikro, Kecil dan Menengah (UMKM), serta merupakan

1 Lihat Pasal 1 ayat (1) Peraturan Pemerintah Nomor 42 Tahun 2007 tentang Waralaba pilihan berwiraswasta dengan resiko yang kecil $^{2}$. Salah satu usaha waralaba yang perkembangannya sangat pesat saat ini yaitu waralaba berjaring seperti minimarket (Indomaret dan Alfamart).

Pertumbuhan usaha minimarket dikota-kota besar berkembang secara masif, di kawasan Kota Yogyakarta sendiri, bisnis waralaba minimarket sangat mudah dijumpai, bukan hanya di pinggir jalan besar, namun kita juga dapat menjumpai minimarket tersebut di daerah pemukiman yang padat penduduk. Pertumbuhan usaha minimarket yang semakin pesat tersebut didasari atas adanya Kegiatan masyarakat untuk memenuhi kebutuhan hidupnya yang semakin hari semakin bervariasi, semakin modern dan semakin berkembang. Pemenuhan kebutuhan hidup itu merupakan tujuan dari kegiatan untuk memenuhi kebutuhan sandang, pangan, dan papan yang dapat memberikan perlindungan kepada keluarga atau dirinya bersamaan dengan

\footnotetext{
${ }^{2}$ Adrian Sutedi, Hukum Waralaba, Penerbit
} Ghalia Indonesia, Bogor, 2008, hlm. 127. 
pemenuhan kebutuhan yang sama dari masyarakat lainnya. ${ }^{3}$

Aspek Pembangunan ekonomi telah menghasilkan banyak kemajuan antara lain dalam hal meningkatkan kesejahteraan rakyat. Namun, tidak menutup kemungkinan bahwa kesejahteraan rakyat yang dimaksud hanya dapat dirasakan oleh segelintir orang saja dimana mereka memilikii kemampuan kekuasaan didalamnya. ${ }^{4}$

Pertumbuhan waralaba yang semakin berkembang di kawasan Yogyakarta dalam menjawab kebutuhan konsumennya, merupakan suatu bentuk persaingan yang tentunya setiap pelaku usaha memiliki target bisnis masing-masing untuk mendapatkan keuntungan. Sehingga, berbagai upaya dilakukan dengan mengelaborasikan sumber daya yang dimiliki untuk meraih kepuasan maksimal. ${ }^{5}$ Sebagai upaya menghindari sisi negatif dari persaingan, perlu dibuat suatu aturan yang jelas, sehingga persaingan dapat

\footnotetext{
3 Rahayu, A. I. (2020) KEHADIRAN USAHA WARALABA ALFAMART DAN INDOMARET TERHADAP WARUNG-WARUNG KECIL DITINJAU DARI UNDANG-UNDANG NO. 20 TAHUN 2008, LEX ET SOCIETATIS, Vol. 07., No. 07. Pp. 170-180.

${ }^{4}$ Shaleh, A. I \& Akhyar, D. S. (2021) PENYELESAIAN KREDIT MACET MELALUI FORUM NON LITIGASI PADA PROSES KEPEMILIKAN RUMAH DI PT BANK TABUNGAN NEGARA CABANG PEKANBARU, Jurnal Era Hukum, Vol 19, No 1, Pp. 131-144.

${ }^{5}$ Sukanto Reksohadiprodja dan Tindriyo Gito Sudarmo, Management Produksi (Yogyakarta:BPFE UGM 2000), Cet. Ke-3, hlm. 57
}

berjalan dengan baik, yang membuat pelakupelaku usaha kecil tetap dapat menjalankan usaha disamping pelaku-pelaku usaha besar tetap dapat menjalankan usahanya. ${ }^{6}$

Berdasarkan paparan tersebut, guna menciptakan suatu konsep pengaturan yang dapat mengakomodir seluruh kepentingan pelaku usaha. Sebagai salah satu agenda terpenting dalam pembenahan tata pemerintahan yang baik. Maka, penelitian ini merupakan suatu bentuk ikhtiar dalam memberikan gagasan yang bersifat kompeherensif, berkaitan dengan keberadaan usaha waralaba minimarket di kawasan Yogyakarta.

Kajian ini dilatarbelakangi atas berbagai urgensi permasalahan berdasar pada Beberapa faktor terkait proses penegakan hukum yang diungkapkan oleh Lawrence M. Friedman, yaitu komponen substansi, struktur, dan kultur hukum ${ }^{7}$. Pertama, Permasalahan yang muncul pada aspek substansi, terletak pada Peraturan Walikota Yogyakarta Nomor 79 Tahun 2010 tentang Pembatasan Usaha Waralaba Minimarket di Kota Yogyakarta. Pengaturan

6 Ditha Wiradiputra, Hukum Persaingan Usaha Indonesia, Modul untuk Retooling Program Under Employee Graduastes at Priority Disiciplines unde TPSDP DIKTI (Jakarta: 14 September 2004)

${ }^{7}$ Sajipto Rahardjo, 2009, Penegakan hukum; Suatu Tinjauan Sosiologis, ctk. Kedua, Genta Publishing, Yogyakarta, hlm.7 
dalam substansi tersebut sejatinya telah menerapkan pengakomodiran jumlah keberadan waralaba minimarket sebanyak 52 unit. Namun, faktanya dilapangan keberadaan waralaba sebanyak 52 unit tersebut telah terpenuhi sejak tahun $2009 .{ }^{8}$ Di sisi lain Sebagaimana merujuk pada data dari Dinas Perindustrian Perdagangan dan Koprasi dan Dinas Perizinan Yogyakarta tercatat sampai dengan tahun 2013 terdapat 75 minimarket (52 diantaranya berbentuk waralaba) dan 14 supermarket ${ }^{9}$

Pada aspek Substansi pengaturan lainnnya, ditemukan bahwa Minimarket Indomaret diduga melanggar UndangUndang Larangan Praktik Monopoli dan Persaingan Usaha Tidak Sehat pada pasal 25 ayat (1) yang berbunyi

"Pelaku Usaha dilarang menggunakan posisi dominan baik secara langsung maupun tidak langsung untuk: a) menetapkan syarat-syarat perdagangan dengan tujuan untuk mencegah dan atau menghalangi konsumen memperoleh barang dan atau jasa yang bersaing, baik

\footnotetext{
${ }^{8}$ Eka Arifa Rusqiyati, Yogyakarta Tidak Keluarkan Izin Minimarket Wiralaba Baru, jogja.antaranews.com di akses dari http://jogja.antaranews.com/berita/332530/yogyakart a-tidak-keluarkan-izin-minimarket-waralaba-baru pada tanggal 8 Desember 2021 Pukul 20:23

9 www.ejournal.undip.ac.id , Sadino dan Joesron Ali Syahbana,2014, Pasar Tradisional Versus Pasar Modern di Daerah Perkotaan.
}

dari segi harga maupun kualitas, atau b) membatasi pasar dan pengembangan teknologi, atau c) menghambat pelaku usaha lain yang berpotensi menjadi pesaing untuk memasuki pasar bersangkutan.

Pasal 1 ayat (4) karena memiliki posisi dominan, yaitu menguasai pangsa pasar karena kemampuan keuangan dan kemampuan akses pasokan. Pada realitanya, semakin membanjir bisnis waralaba ini, dengan para pengusaha yang dapat mematikan sektor-sektor perekonomian kecil yang lain. ${ }^{10}$

Berkaitan dengan aspek pembatasan, keberadaan waralaba minimarket hanya dibatasi dengan pasar tradisional yang jaraknya minimal 400 meter, namun tidak ada pembatasan berkaitan dengan keberadaan UMKM setempat. Padahal telah jelas diterangkan bahwa dalam pemberian perizinan perlu memperhatikan pemberdayaan UMKM disekitarnya. ${ }^{11}$ Pada prakteknya, tidak sedikit terdapat minimarket Indomaret yang letaknya berdekatan dengan toko tradisional,

10 Undang-Undang Larangan Praktek Monopoli Dan Persaingan Usaha Tidak Sehat No. 5 Tahun 1999.

${ }^{11}$ Lihat Pasal 7 ayat 2 huruf d Peraturan Walikota Nomor 79 Tahun 2010 tentang Pembatasan Usaha Waralaba Mini Market di Kota Yogyakarta 
bahkan jarak sendiri kurang 500 meter dari yang ditentukan oleh peraturan tersebut.

Kedua, Melihat kerangka bangunan hukum, maka bagian yang tidak dapat dipisahkan dari pengamatan adalah aspek penegakan hukum (law enforcement), bagaimana penegakan hukum paling tidak pada pengertian penegakan hukum dalam arti luas yaitu meliputi pelaksanaan dan penerapan hukum terhadap setiap pelanggaran atau penyimpangan hukum yang dilakukan oleh subjek hukum, serta dalam arti yang sempit merupakan kegiatan penindakan terhadap setiap pelanggaran atau penyimpangan terhadap peraturan perundang-undangan. ${ }^{12}$

Aspek penegakan hukum dalam kaitannya dengan kasus pendirian waralaba disini adalah ketika waralaba tersebut didirikan secara ilegal atau tanpa adanya perizinan yang sah dapat terus beroprasi, maka akan muncul beberapa kemungkinan.

Pertama, terjadinya suap menyuap antara pihak pemilik waralaba dengan pemerintah daerah. Kedua, pengawasan dari pemerintah daerah yang kurang tegas dalam pendirian peraturan tersebut dan yang ketiga adanya kepentingan pribadi atau golongan yang

12 Sabian Utsman,, Menuju Penegakan Hukm Rseponsif, ctk. Pertama, Pustaka Pelajar, Yogyakarta, 2008, hlm. 30 lebih diutamakan. Dalam hal ini menggambarkan bahwa sistem birokrasi di Indonesia terutama di kota Yogyakarta ini sangat buruk karena adanya birokrasi gemuk dan tumpang tindih antara kewenangan lembaga baik dari sisi metode,sistem, dan prosedur kerja yang kurang tertib. Pegawai negeri sipil dianggap belum profesional, belum netral dan sejahtera, praktik korupsi,kolusi dan nepotisme masih mengakar. Singkronisasi program belum terarah; serta disiplin dan etos kerja aparatur negara masih rendah. Hal ini dipicu juga dengan diamnya masyarakat yang membuat kasus ini terus berkembang ${ }^{13}$

Ketiga, pada aspek kultur yakni fakta sosial didalam ruang lingkup bermasyarakat. Perlu dipahami bahwa pertumbuhan usaha waralaba yang dapat dikatakan cukup agresif adalah ekspansi usaha Indomaret. Anak perusahaan Pt. Indomaret Prismatama ini adalah salah satu bentuk usaha ritel modern yang cukup sukses. Pada prakteknya usaha indomaret tersebut tidak hanya dijadikan sarana jual beli produk-produk eceran. Namun sebagai penyedia jasa seperti pembelian tiket kereta api dan pembayaran tagihan listrik serta tv kabel. Minimarket tersebut juga menjadikan

13 Pandji Santosa, Administrasi Publik: Teori dan Aplikasi Good Governance, Bandung: PT. Reflika Aditama, 2008 hlm. 1. 
nama tokonya sebagai merek dagang dari beberapa produk yang di produksinya sendiri. Secara tidak langsung hal tersebut menjadikan kategorisasi gerai menjadikan indomaret sebagai meeting point, dan saran efekif dalam mendapatkan pelanggan. Berikut Perbandingan antara toko modern dan tradisional tersebut dapat dilihat melalui bagan berikut :

\begin{tabular}{|c|c|c|}
\hline $\mathrm{NO}$ & Pasar Tradisional & Toko Modern \\
\hline 1 & $\begin{array}{l}\text { Harga bisa } \\
\text { ditawar, harga } \\
\text { tergantung pada } \\
\text { kesepakatan pen- } \\
\text { jual dengan } \\
\text { pembeli }\end{array}$ & $\begin{array}{l}\text { Konsumen tidak } \\
\text { dapat menawar } \\
\text { harga kare- na } \\
\text { terdapat label har- } \\
\text { ga khusus pada } \\
\text { barang yang dijual } \\
\text { (barcode) }\end{array}$ \\
\hline 2 & $\begin{array}{l}\text { Barang yang } \\
\text { dijual lebih } \\
\text { mencirikan } \\
\text { komoditi lokal. }\end{array}$ & $\begin{array}{l}\text { Barang } \\
\text { dijual } \\
\text { Variatif }\end{array}$ \\
\hline 3 & $\begin{array}{l}\text { Penjual bersikap } \\
\text { aktip dalam } \\
\text { melayan pembeli } \\
\text { sehingga } \\
\text { terkadang } \\
\text { pembeli kurang } \\
\text { bebas dalam } \\
\text { melakukan } \\
\text { pembelian. }\end{array}$ & $\begin{array}{l}\text { Konsumen dapat } \\
\text { memilih barang } \\
\text { sendiri sesui } \\
\text { dengan } \\
\text { keinginannya baru } \\
\text { dibayarkan } \\
\text { (sebagaimana } \\
\text { praktek } \\
\text { swalayan dan } \\
\text { minimarket }\end{array}$ \\
\hline
\end{tabular}

\begin{tabular}{|r|l|l|}
\hline & & modern. \\
\hline 4 & $\begin{array}{l}\text { Kenyamanan dan } \\
\text { kebersihan dalam } \\
\text { berbelanja } \\
\text { kurang }\end{array}$ & $\begin{array}{l}\text { Tingkat } \\
\text { kenyamanan dan } \\
\text { kebersihan jauh } \\
\text { lebih baik. }\end{array}$ \\
\hline 5 & Waktu Pelayanan & $\begin{array}{l}\text { Waktu pelayanan } \\
\text { lebih lama bahkan } \\
\text { ada yang 24 (Dua } \\
\text { terbatas }\end{array}$ \\
& puluh empat) jam \\
\hline
\end{tabular}

Tabel 2 : Perbandingan Pasar Tradisional dan Toko Modern

Berbagai bentuk keunggulan yang dimiliki mini market modern tersebut selain yang disebutkan di atas. Salah satunya adalah pada aspek ekonomis. Hal tersebut menimbulkan hampir seluruh konsumen atau pelanggan yang setia berbelanja di usaha ritel kecil pada akhirnya beralih ke mini market modern. ${ }^{14}$ Ketimpangan tersebut menimbulkan tidak terkakomodirnya kesejahteraan rakyat kecil, bahkan pemerintah sebagai pihak pelayan publik dalam hal ini terkesan membiarkan dan bersikap apatis tanpa adanya pengaturan lebih lanjut, guna memastikan tercptanya pengakomodiran antar sesama pelaku usaha yang selaras.

\footnotetext{
${ }^{14}$ http://digilib.unpas.ac.id/files/disk1/111/jb ptunpaspp-gdl-dikybudima-5504-1-bab1.pdf Diakses pada tanggal 9 Desember 2021 pukul 15.00
} 
Bentuk penggunaan sistem perkulakan, perkembangan gerai-gerai waralaba misalnya Indomaret yang mengalami pertumbuhan secara pesat tidak lain didukung dengan adanya penggunaan sistem perkulakan dimana barang-barang yang akan dipasarkan tersebut didapat dari PT Indomarko selaku badan usaha yang menaunginya. Sehingga tidak perlu khawatir pada urusan permodalan. Jika, dibandingkan dengan usaha biasa misalnya pedagang grosi yang dalam menja;ankan usahanya harus kembali memutar otak dalam urusan pengadaan barang dan menjual kembali terhadap konsumen dengan harga yang biasa, hal tersebut akan menjadi tantangan tersendiri yang perlu diselesaikan. Pada prakteknya tantangan tersebut akn sulit untuk diselesaikan bila tidak dibarengi kemampuan dan kompetensi yang jelas.

Berdasarkan hal tersebut, maka dapat pahami bahwa perilaku penegak hukum progresif memiliki dasar filosofi bahwa hadirnya hukum adalah sebagai lembaga yang bertujuan agar manusia dapat mempunyai kehidupan yang adil. Sejahtera dan membuat manusia menjadi bahagia. ${ }^{15}$ Artinya kehadiran hukum bukan untuk

\footnotetext{
${ }^{15}$ Mahmud Kusuma, Menyelami Semangat Hukum Progresif; Terapi Paradigmatik atas Lemahnya, Penegakan Hukum Indonesia, ctk. Pertama, AntonyLib Bekerjasama LHSP, Yogyakarta, 2009, hlm. 30
}

dirinya sendiri, namun untuk sesuatu hal yang lebih luas, yaitu: untuk manusia itu sendiri, kebahagiaan, kesejahteraan, dan kemuliaan manusia. $^{16}$

Secara konsepsional, maka inti dan arti penegakan hukum terletak pada kegiatan menyerasikan hubungan nilai-nilai yang terjabarkan di dalam kaidah-kaidah yang mantap dan sikap tindak sebagai rangkaian penjabaran nilai tahap akhir, untuk menciptakan, melahirkan dan mempertahankan kedamaian pergaulan hidup $^{17}$ fenomena tersebut muncul ekspektasi agar hukum dapat ditegaskan secara tegas dan konsisten, karena ketidakpastian hukum dan kemerosotan wibawa hukum akan melahirkan krisis hokum.

Tugas dan kewenangan pemerintah adalah untuk menjaga ketertiban dan keamanan diamna tugas ini dilaksanakan melalui suatu bentuk pengaturan yang terbentuk dalam suatu ketetapan. ${ }^{18}$ Adanya dampak negatif akibat kemunculan toko modern berjaring seperti alfamart dan

${ }^{16}$ Faisal, Menggagas Pembaharuan Hukum Melalui Studi Hukum Kritis, Jurnal Ultimatum, Edisi II. STIH IBLAM, Jakarta, 2008, hlm. 17

17 Soerjono Soekanto, Faktor-Faktor Yang Mempengaruhi Penegakan Hukum, PT. Rajagrafindo Persada, Jakarta, 2012, hlm. 5

18 Ridwan, H.R., Hukum Administrasi Negara, Raja Grafindo, Jakarta, 2006, hlm. 198 
indomaret , maka kedepan diperlukan kebijakan pemerintah dalam mengatur keberadaan tersebu secara lebih kompeherensif, sehingga pasar tradisional dan usaha ekonomi kecil mampu tumbuh secara seimbang, saling mengisi, melengkapi dan saling memperkuat satu sama lain. ${ }^{19}$

Pemerintah sebagaimana pengaturan yang berlaku diamanatkan untuk memberikan suatu bentuk pemberdayaan bagi para pelaku usaha, namun fakta yang terjadi dilapangan justru sebaliknya. Ketidak adanya keberpihakan pemerintah menimbulkan sebagian pasar tradisional dan pedagang kelontong gulung tikar. Jika hal ini tetap berlanjut dikemudian hari, amka diprediksikan selama delapan tahun ke depan seluruh pasar tradisional di Indonesia hanya tinggal hitungan jari. $^{20}$

\section{Rumusan Masalah :}

1. Bagaimana Implementasi Peraturan Walikota Yogyakarta No.79 Tahun 2010 Tentang Pembatasan Usaha Waralaba Minimarket Di Kota Yogyakarta terhadap keberadaan usaha

\footnotetext{
19 Setyorini Tatik, "Kebijakan Pemkab Bantul dalam Menangani Menjamurnya Toko Modern”. Jurnal PMI Vo. X No 2 Maret 2013, hlm. 80

${ }^{20}$ Novi Hasanah, Skripsi, "Dampak Kehadiran Plaza Ambarukmo Tehradap Aktivitas Jual Beli di Psar Tradisional Gowok Yogyakarta", 2009, hlm. 5 tidak diterbitkan.
}

Indomaret dan Alfamart di kota Yogyakarta?

2. Bagaimana Sikap Pemerintah Terhadap Keberadaan Usaha Indomaret dan Alfamart di Kota Yogyakarta ?

\section{TujuanPenelitian}

1. Untuk Mengetahui Implementasi Peraturan Walikota Yogyakarta No.79 Tahun 2010 Tentang Pembatasan Usaha Waralaba Minimarket Di Kota Yogyakarta terhadap keberadaan usaha Indomaret dan Alfamart di kota Yogyakarta

2. Untuk Mengetahui Sikap Pemerintah Terhadap Keberadaan Usaha Indomaret dan Alfamart di Kota Yogyakarta.

\section{Metode Penelitian :}

Jenis penelitian yang digunakan dalam Penelitian ini merupakan penelitian jenis Hukum Normatif-Empiris mengenai implementasi ketentuan hukum normatif dalam aksinya pada setiap persitiwa hukum. Mengkompair Bahan Pustaka serta aturanaturan peraturan perundang-undangan yang terkait dengan peristiwa hukumyangada di lapangan dengan melakukan wawancara kepada instansi yangberwenang dalam melakukan penegakan hukum ini.

\section{A. Hasil Penelitian dan Pembahasan}

\section{Implementasi Peraturan Walikota Yogyakarta No.79 Tahun 2010 Tentang Pembatasan Usaha Waralaba Minimarket Di Kota Yogyakarta terhadap keberadaan usaha Indomaret dan Alfamart di kota Yogyakarta}


Impementasi Peraturan Walikota Nomor 79 Tahun 2010 di Kota Yogkarta memiliki berbagai bentuk poin permasalahan yang ditemukan penulis. Sebagaimana yang telah disebutkan sebelumnya, Pertama, pembatasan jumlah waralaba berdasar aturan yang ada adalah sebanyak 52 unit. Namun, dalam faktanya saat ini telah berdiri lebih dari 52 unit waralaba di kota Yogyakarta ${ }^{21}$. Pokok permasalahan adalah adanya kerancuan tentang pengertian redaksi dari Waralaba pada pengaturan tersebut dan pandangan masyarakat umum. Berdasarkan Pasal 1 PP Nomor 42 Tahun 2007 waralaba memiliki arti yaitu hak khusus yang dimiliki oleh orang perseorangan atau badan usaha terhadap sistem bisnis dengan ciri khas usaha dalam rangka memasarkan barang dan/atau jasa yang telah terbukti berhasil dan dapat dimanfaatkan dan/atau digunakan oleh pihak lain berdasarkan perjanjian waralaba.

Waralaba adalah kerja sama dalam bidang usaha dengan bagi hasil sesuai dengan kesepakatan, hak kelola, hak pemasaran. $^{22}$ Berdasarkan hal tersebut maka pada waralaba berlaku perjanjian antara dua pihak yaitu franchise dan franchisor dimana perjanjian tersebut akan berlaku sebagai Undang-Undang

21 Eka Arifa Rusqiyati, Yogyakarta Tidak Keluarkan Izin Minimarket Wiralaba Baru, jogja.antaranews.com di akses dari http://jogja.antaranews.com/berita/332530/yogyakart a-tidak-keluarkan-izin-minimarket-waralaba-baru pada tanggal 10 Desember 2021 Pukul 19.00

${ }^{22}$ Fitri A \& Anny, Kamus Bahasa Indonesia Bergambar, Makasar, Galeri Lontara, 2008, hal.954

bagi kedua pihak $^{23}$. Perjanjian tersebutlah yang membedakan antara minimarket waralaba (franchise) dengan minimarket toko cabang.

Oleh karena itu, jika pada suatu perjanjian usaha tidak terdapat perjanjian franchise maka tidak dapat dikatakan waralaba melainkan bentuk usaha toko cabang. Seperti halnya PT.IndoMaret merupakan waralaba namun pada prakteknya toko-toko indomaret yang ada di sekitar jalan daerah Yogyakarta merupakan toko cabang. Sebab, tidak adanya perjanjian franchise akan tetapi miliknya langsung directly dari pusat PT.IndoMaret. Faktanya, didalam PERWAL No.79 Tahun 2010 mengatur pembatasan minimarket hanya ditujukan bagi mereka yang berbentuk waralaba tidak terhadap toko cabang, sedangkan tidak diatur keberedaan minimarket toko cabang. Sehingga, tidak menutup kemungkinan bahwa kuota yang memenuhi jumlah kapasitas pembatasan minimarket waralaba adalah toko cabang. Perbedaan penafsiran pada pandangan masyarakat inilah yang kemudian menjadi bentuk kesalahpahaman tersendiri disebagian kalangan, berkaitan dengan kasus pendirian usaha Indomaret dan Alfamart yang semakin masif perkembangannya.

Kedua,Berdasarkan Peraturan Walikota Nomor 79 Tahun 2010 Tentang

\begin{tabular}{|c|c|c|}
\hline${ }^{23}$ Munir & Fuady,Pengantar & Hukum \\
\hline Bisnis:Menata & Bisnis Modern & di $\quad E$ \\
\hline
\end{tabular}


Pembatasan Usaha Waralaba

Minimarket. Terdapa penyelewengan aturan dilapangan seperti waralaba minimarket yang jaraknya kurang dari 400 meter dari pasar tradisional, salah satunya Indomaret yang terletak di Jalan Bhayangkara dekat dengan Pasar Pathuk dan Alfamart yang terletak di Jalan Imogiri Timur dekat dengan Pasar Giwangan. Berdasarkan hasil wawancara yang kami lakukan dengan pihak bagian hukum pemerintah kota Yogyakarta berkaitan dengan peraturan pembatasan jarak antara pendirian waralaba dan pasar tradisional dianggap tidak relefan untuk dicantumkan. Sebab pada faktanya antara minimarket dengan pasar tradisional keduanya memiliki target pemasaran yang berbeda. Oleh karena itu, pencantuman peraturan jarak waralaba dengan pasar tradisional bukan merupakan permasalahan yang urgent untuk ditindak lanjuti. ${ }^{24}$

Ketiga,didalam peraturan pendirian waralaba di kota Yogyakarta hanya terdapat satu peraturan pembatasan terkait pada bidang usaha waralaba berjaring. Hal tersebut menjadi celah bagi usaha minimarket dengan bentuk bisnis toko cabang lebih leluasa melakukan pendirian usaha tanpa adanya suatu tekanan. Seyogianya pada ketentuan yang akan datang perlu adanya pebatasan tidak hanya pada

24 Muhammad Rizky Novriady, Nasrudin (2021) Dampak Berkembangnya Waralaba Minimarket(Indomaret Dan Alfamart) Terhadap Pendapatan Pedagang Kecil Atau Toko Kelontong Di Kecamatan Banjarmasin Utara Kota Banjarmasin, Jurnal Ilmu Ekonomi dan Pembangunan, Vol. 4 No. 2, Pp. 453-462. minimrket berjaring atau waralaba. Akan tetapi, mencakup pula toko cabang.

\section{Sikap Pemerintah Terhadap} Keberadaan Usaha Indomaret dan Alfamart di Kota Yogyakarta

Pada aspek ini penulis mencoba untuk mengulas peran atau kebijakan yang dilakukan Pemerintah Kota Yogyakarta terhadap keberadaan Usaha Indomaret dan Alfamart di Kota Yogyakarta. Penulis menemukan terdapat dua aspek kebijakan pemerintah yang dapat dinilai secara positif dan negatif. Pada aspek positif, Dari penelitian dan wawancara yang penulis dapatkan bahwa pemerintah TELAH melakukan pencegahan agar kios-kios kecil tersebut tidak mati oleh toko modern. Yaitu, pemerintah telah membantu kios-kios kecil melalui berbagai bentuk. Memberikan arahan agar mampu bersaing dengan toko-toko modern, pelatihan terhadap pemiliki kios dan penyuluhan. Di sisi lain, pemerintah tidak memberikan modal atau uang untuk mereka melakuka usaha. Tapi pemerintah hanya memberikan bantuan seperti halnya pembelajaran dan pengeahuan bagaimana mereka agar mampu bersaing dan berkompetensi secara sehat. Hal tersebut dilakukan untuk memastikan ios-kios kecil dapat berdiri secara mandiri.

Pada Aspek Negatif, Penulis kecewa dengan kebijakan pemerintah pusat yang mengeluarkan peraturan Menteri Dalam Negeri Nomor 19 Tahun 
2017 tentang pencabutan izin gangguan. Pemerintah beralasan Penetapan Izin Gangguan di Daerah sudah tidak sesuai dengan perkembangan keadaan, dan tuntutan kemudahan berusaha (ease of doing business) di Indonesia sehingga perlu dicabut. Pencabutan tersebut menurut hemat penulis menjadi bentuk ketidakpastian hukum. Izin Gangguan pada prakteknya berfungsi untuk mencegah kemungkinan-kemungkinan yang buruk yang mungkin akan terjadi. Seperti halnya suatu kegiatan usaha pasti sedikitnya dapat menyebabkan terganggunya suatu kehidupan di sekitar tempat kegiatan usaha tersebut. Jika minimarket Indomaret dan Alfamart yang menyalahi izin gangguan, dan telah diproses sesuai aturan hukum. Kemudian aturan izin gangguan dicabut, akan mempersilahkan kembali pihak minimarket yang bersangkutan menjalankan usahanya, padahal usaha tersebut dapat menimbulkan kerugian bagi pihak lain. Menjamurnya toko cabang yang ada justru menimbulkan kekhawatiran membuat toko-toko retail atau kios-kios kecil yang ada disekeliling akan mati dan tertutup minimarket dengan bentuk usaha waralaba atau toko cabang.

\section{Desain pengaturan ideal terkait} keberadaan usaha Indomaret dan Waralaba di Kota Yogyakarta

Desain pengaturan yang diberikan hendaknya merujuk pada konsep Lawrence M. Friedman dalam legal system mendeskripsikan tentang keberlakuan hukum atau efektivitas hukum, di mana ia menegaskan bahwa keberlakuan kaidah hukum dipengaruhi olah 3 (tiga) elemen dasar yaitu structure, substance dan culture. Pada aspek substansi menurut Friedman adalah $^{25}$

“.....is composed of substantive rules and rules about how institutions should behave... ".

Pada prinsipnya substansi hukum itu sendiri adalah berkaitan dengan aturanaturan hukum yang sesungguhnya dan aturan tentang bagaimana institusi harus bertindak. Dari makna substansi tersebut jelaslah bahwa substansi suatu aturan itu harus jelas dan mempunyai value sebagaimana dinyatakan oleh Bruggink. Jika suatu substansi hukum sudah memiliki nilai, pada saat itu pulalah nilai itu dapat dievaluasi tentang keberlakuan atau efektivitasnya. Jadi suatu ketentuan peraturan perundangundangan dianggap mempunyai nilai, pada saat substansinya mewujudkan nilai-nilai yang dalam masyarakat itu sendiri.

Oleh karena itu, pada aturan yang akan datang perlu adanya spesifikasi aturan

${ }^{25}$ Lawrence M. Friedman, The Legal System, A Social Science Perspective, (New York: Russell Sage Foundation, 1975), hal. 14. 
berkaitan dengan 5 urgensi permasalahan.

Pertama, keberadaan toko cabang, tidak hanya pada minimarket dengan sistem waralaba berjaring. Hal tersebut dipengaruhi oleh hal-hal sebagai berikut :

a. Memberdayakan Usaha Mikro, Kecil dan Menengah di wilayah Daerah.

b. Mencegah pembentukan struktur pasar yang dapat melahirkan persaingan yang tidak wajar dalam bentuk monopoli, oligopoly dan monopsoni yang merugikan Usaha Mikro, kecil dan Menengah.

c. Mencegah terjadinya penguasaan pasar dan pemusatan usaha oleh orang-perseorangan atau kelompok orang atau badan tertentu yang dapat merugikan Usaha Mikro, Kecil dan Menengah.

d. Menumbuhkan dan meningkatkan kemampuan Usaha Mikro, Kecil dan Menengah menjadi usaha yang tangguh dan mandiri.

e. Meningkatkan peran Usaha Mikro, Kecil dan Menengah dalam perluasan kesempatan kerja dan berusaha serta peningkatan dan pemerataan pendapatan yang seimbang, berkembang dan berkeadilan.
Kedua, Hendaknya pemerintah tidak mencabut penggunaan izin fungsi gangguan bagi sebuah minimarket, agar terciptanya bentuk kepastian hukum dan kemanfaatan. Selama ini, tindakan yang dilakukan terhadap waralaba minimarket yang terbukti melakukan pelanggaran karena tidak memiliki izin, maka pemilik minimarket akan langsung diundang ke Dinas Ketertiban kemudian dilakukan penyidikan. Setelah itu diajukan ke pengadilan. Setelah putusan pengadilan maka minimarket tersebut akan diberikan sanksi. ${ }^{26}$ Izin Gangguan begitu diperlukan bagi tiap tempat usaha dikarenakan adanya hal-hal yang membatasi dalam banyak sisi tempat usaha tersebut, khususnya mengenai hal dampak lingkungan. Dampak penting dari suatu usaha tidak selama positif, sering juga negatif. Seperti halnya suatu kegiatan usaha pasti sedikitnya dapat menyebabkan terganggunya suatu kehidupan lingkungan di sekitar tempat kegiatan usaha tersebut. Ketentuan memberikan izin gangguan hendaknya harus mempertimbangkan kepentingan pengusaha kecil dan mikro yaitu dengan menambahkan penggolongan

\footnotetext{
26 Eva Marta Claudia, Pelaksanaan Peraturan Walikota Yogyakarta Nomor 79 Tahun 2010 Tentang Pembatasan Usaha Waralaba Minimarket Di Kota Yogyakarta, Universitas Atmajaya Yogyakarta, 2016, hlm. 5
} 
atau penetapan kriteria industri rumah tangga sebagai objek izin gangguan.

Ketiga, Dalam menanggapi kasus ini, perlu dibentuknya Peraturan mengenai pendirian minimarket dikota Yogyakarta baik yang berbentuk waralaba maupun bukan. Hal ini agar sesuai dengan prinsip keadilan, kepastian, dan kemanfaatan Hukum. Dalam ajaran teori penegakan hukum, terdapat tiga prinsip yang harus terpenuhi yaitu prinsip keadilan, prinsip kemanfaatan, dan prinsip kepastian.

Dalam PERWAL YOGYAKARTA NO.79 Tahun 2010 hanya mengatur tentang pembatasan waralaba berjaring, sedangkan tidak ada peraturan yang membatasi toko cabang, namun disisilain ketika toko cabang tersebut dibatasi maka sama saja dengan membatasi seseorang untuk mendirikan suatu usaha. Maka, solusi yang dapat ditawarkan dari Peraturan yang baru ini adalah pembatasan tentang ukuran bangunan yang dapat dijadikan sebagai toko cabang, dimana ukuran bangunan tersebut disama ratakan dengan ukuran bangunan toko kelontong. Artinya peraturan yang baru tersebut dapat mengakomodir para investor yang ingin mendirikan toko cabang, tanpa mengesampingkan toko kelontong atau pengusaha kecil disekitarnya. Dari pembentukan peraturan diatas diharapkan ketiga prinsip penegakan hukum di Indonesia dapat terpenuhi.

Keempat, berkaitan dengan pengertian waralaba didalam PERWAL Yogyakarta No.79 Tahun 2010 dimana redaksi tersebut tidak diberikan pengertian secara jelas antara waralaba dengan toko cabang yang membuat kesalahan pemahaman antara waralaba dan toko cabang. Dalam mengatasi permasalahan tersebut, maka dengan membentuk peraturan walikota yang baru perlu dicantumkan adanya penjelasan pengertian secara rinci agar tidak terjadi kerancuan dalam penafsiran pengertian waralaba.

Kelima, pengaturan yang mengatur tentang jarak antara minimarket dengan pasar tradisional. Peraturan tersebut dianggap sudah tidak lagi relevan untuk dicantumkan kedalam perwal tersebut, karena antara minimarket dan pasar tradisional memiliki target pemasaran yang berbeda, artinya pembangunan minimarket tidak akan berpengaruh pada kondisi perekonomian pasar tradisional. pembangunan minimarket sendiri secara ekonomi mempengaruhi tingkat pendapatan pedagang kecil atau yang biasa disebut dengan toko kelontong. Untuk mengatasi hal 
tersebut dapat dilakukan dengan mencantumkan jarak antara minimarket dengan toko kelontong. dalam pencantumannya, bisa dilakukan dengan 1:400 artinya didalam pembangunan 1 toko kelontong maka jarak pembangunan minimarket harus dibangun minimal $400 \mathrm{~m}$ dari masing-masing toko kelontong tersebut, jika dilingkungan tersebut terdapat lebih dari 1 toko kelontong, maka batas minimal dari minimarket tersebut adalah 500 meter, dan hal tersebut berlaku kelipatan. Maka dengan adanya peraturan tersebut tidak membatasi antara pendirian minimarket cabang dan pembangunan tersebut tidak menganggu toko kelontong yang ada.

Keenam, setelah adanya pembentukan peraturan baru maka yang diperlukan adalah system pengawasan yang ketat antara pemerintah dan juga masyarakat itu sendiri. Pelaksanaan dari peraturan ini dapat dilakukan mulai dari jajaran pemerintahan antara lain dibidang perizinan. Izin sendiri menjadi factor penting dalam melaksanakan sesuatu, dimana ketika izin dapat dikeluarkan maka akan menjadi sebual legitimasi yang $\operatorname{sah}^{27}$. Dengan dikeluarkan izin tersebut, maka bangunan menjadi legal dan dapat didirikan. Artinya, perlu ada

${ }^{27}$ Ridwan HR, Hukum Administrasi Negara, Raja Grafindo Persada, Jakarta, 2006, hlm. 207 perizinan yang ketat dari pemerintah sendiri. Selain dari pemerintah, perlu adanya kesadaran dari masyarakat mengenai pentingnya mematuhi peraturan yang telah dibuat.

Ketujuh, sebagai usaha dalam mengembangkan usaha kecil masyarakat perlu diadakannya program pemerintah yaitu suatu pelatihan. Pelatihan pemerintah selama ini yang dilakukan hanya berbentuk sosialisasi bagi pelaku usaha mikro maupun pemilik toko kelontong, salah satunya sosialisasi yang diselenggarakan PT Sumber Alfaria Trijaya Tbk yang bekerjasama dengan pemerintah. Sosialisasi tersebut berisi tentang managemen pengelolaan usaha modern seperti minimarketminimarket modern yang ada di kota Yogyakarta $^{28}$. Program tersebut merupakan program positif dari pemerintah, namun pada faktanya saat ini yang dibutuhkan oleh masyarakat adalah bukan hanya sekedar penyuluhan namun terdapat praktek didalamnya. Maka, dari konsep bantuan pemerintah dapat ditambahkan dengan adanya pendampingan secara langsung kepada pedagang kelontong bagaimana mengimplementasikan konsep managemen

\footnotetext{
${ }^{28}$ http://www.harianjogja.com/baca/2016/10/ 06/umkm-jogja-usaha-kecil-di-sekitar-alfamartdiberi-pelatihan-758686 diakses pada tanggal 9 Desember 2021 pukul 4 :08 WIB
} 
toko modern, sehingga pedagang kelontong mampu bersaing dengan minimarket yang ada. Dalam menjalankan program ini pemerintah dapat bekerjasama dengan perguruan tinggi di kota Yogyakarta sebagai kota pelajar tidak sulit untuk bekerja sama dengan perguruan tinggi. Selain bermanfaat untuk pedagang kelontong, program ini juga dapat sebagai media pembelajaran bagi mahasiswa dan mahasiswi agar dapat mengimplementasika ilmunya kepada masyarakat.

\section{Penutup}

\section{Kesimpulan}

Implementasi Peraturan Walikota Yogyakarta Nomor 79 Tahun 2010 tentang pembatasan usaha waralaba minimarket di Kota Yogyakarta belum berjalan dengan baik, aturan yang ada untuk usaha waralaba sendiri berdasarkan aturan sebanyak 52 unit, sementara pada prakteknya lebih dari 52 unit waralaba. Waralaba yang dimaksud dalam perwal ini tidak terhadap toko cabang. prakteknya terdapat penyelewengan aturan dilapangan terkait jarak antara waralaba kurang dari 400 meter dari pasar trasdisional, dalam perwal hanya menjelaskan peraturan terkait pada bidang usaha waralaba berjaring, sehingga menimbulkan celah untuk melakukan pendirian usaha. Pemerintah telah melakukan pencegahan agar kioskios kecil atau pasar tradisional tidak mati, dengan memberikan arahanuntuk mampu bersaing dan memberikan pelatihan serta penyuluhan, serta pembelajaran, agar memastikan kios-kios atau pasar tradisional dapat bersaing secara mandiri. Adanya pencabutan terkait izin gangguan memberikan ketidakpastian hukum terhadap waralaba yang semakin berkembang pesat di yogyakarta terutama adanya indomaret dan alfamart.

\section{Saran}

Pada aturan yang akan datang perlu adanya spesifikasi aturan yang berkaitan dengan value sebagaimana dinyatakan oleh bruggink, jika suatu substansi hukum telah memiliki nilai, pada saat maka nilai dapat di evaluasi tentang keberlakukannya atau efektivitasnya. Adanya spesifikasi aturan yang berkaitan dengan 5 urgensi permasalahan keberadaan toko cabang tidak hanya pada minimaret sistem waralaba saja tapi harus melihat pengaruh lainnya seperti a) memberdayakan Usaha Mikro Kecil dan Menengah di wilayah daerah b)mencegah pembentukan struktus pasar yang dapat melahirkan persaingan yag tidak wajar dalam bentuk monopoli c) mencega terjadinya penguasaan pasar da pemutusan usaha oleh orag persorangan atau kelompok d)menumbuhkan dan meningkatkan kemampua Usaha Mikro Kecil dan Menengah menjadi usaha yang tagguh dan Mandiri e) meningkatka peran Usaha Mikro Kecil dan Menengah dala perluasan kesempatan kerja. Pemeritnah hendaknya juga tidak melakukan pencabutan izin fungsi gangguan bagi sebuah minimarket, agar terciptanya bentuk kepastian hukum dan kemafaatan salah satunya megenail sisi temapt usaha dalam hal dampak lingkungan. Dalam menanggapi kasus ini, perlu dibentuknya Peraturan mengenai pendirian minimarket dikota Yogyakarta baik yang 
berbentuk waralaba maupun bukan. Hal ini agar sesuai dengan prinsip keadilan, kepastian, dan kemanfaatan Hukum. Dalam ajaran teori penegakan hukum, terdapat tiga prinsip yang harus terpenuhi yaitu prinsip keadilan, prinsip kemanfaatan, dan prinsip kepastian

\section{Daftar Pustaka}

\section{Buku}

Abdul Kadir. Etika Profesi Hukum, PT Ctra Aditya Bakti, Bandung, 2006.

Bagir Manan. Dasar-dasar Perundangundangan Indonesia, Ind-Hill.Co, Jakarta, 1992.

Bagir Manan. Teori dan Politik Konstitusi, Cet . Kedua, FH Ull Press, Yogyakarta 2004.

Budi Winarno. Teori dan proses Kebijakan Publik, Media Pressindo, Jakarta, 2002

Jimly Ash-Shidqie. Hukum Tata Negara dan Pilar-Pilar Demokrasi, Sinar Grafika Tahun, Jakarta, 2011

Jimly Asshiddiqie. Perihal Undang-Undang di Indonesia, Sekretariat Jenderal Mahkamah Konstitusi Republik Indonesia, Jakarta, 2006.

Maria Farida Indrati S. Ilmu PerundangUndangan: Proses dan Teknik Pembentukannya, Kanisius, Yokyakarta, 2007.

Mochtar Kusumaatmadja. Konsep-Konsep Pembangunan Hukum dalam Pembangunan, Alumni-Bandung, 2002.

Muh. Kusnardi dan Hamaily Ibrahim. Hukum Tata Negara Indonesia, Sinar Bakti, Jakarta, 1998. Pedoman dan Petunjuk Polisi Pamong Praja. Dirjen Pemerintahan Umum dan Otonomi Daerah (PUOD), 1995, Jakarta.
Robert J. Kodoatie dan Roestam Sjarief. Pengelolaan Sumber Daya Air Terpadu, Edisi II, Andi, Yogyakarta, 2008.

Rosjidi Ranggawidjaja. Pengantar Ilmu Perundang-undangan Indonesia, Penerbit Mandar Maju, Bandung, 1998.

Satjipto Rahardjo. Negara Hukum Yang Membahagiakan Rakyatnya, Genta Publishing, Yogyakarta, 2009.

Socrates, dalam J.J. Von Schmid. Ahli-Ahli Pikir Besar Tentang Negara dan Hukum, PT. Pembangunan, Jakarta, 1958.

\section{Jurnal}

Shaleh, A. I \& Akhyar, D. S. (2021) PENYELESAIAN KREDIT MACET MELALUI FORUM NON LITIGASI PADA PROSES KEPEMILIKAN RUMAH DI PT BANK TABUNGAN NEGARA CABANG PEKANBARU, Jurnal Era Hukum, Vol 19, No 1, Pp. 131-144.

Rahayu, A. I. (2020) KEHADIRAN USAHA WARALABA ALFAMART DAN INDOMARET TERHADAP WARUNG-WARUNG KECIL DITINJAU DARI UNDANGUNDANG NO. 20 TAHUN 2008, LEX ET SOCIETATIS, Vol. 07., No. 07. Pp. 170-180.

Muhammad Rizky Novriady, Nasrudin (2021) Dampak Berkembangnya Waralaba Minimarket(Indomaret Dan Alfamart) Terhadap Pendapatan Pedagang Kecil Atau Toko Kelontong Di Kecamatan Banjarmasin Utara Kota Banjarmasin, Jurnal Ilmu Ekonomi dan Pembangunan, Vol. 4 No. 2, Pp. 453-462.

\section{Undang-Undang}

Undang-Undang Dasar 1945, PT Balai Pustaka, Jakarta 2014. 
Peraturan Bupati Sleman Nomor 57 Tahun 2016 tentang Penyelenggaraan Pemondokan. Undang-Undang Nomor 8 Tahun 2011 tentang Peraturan Perundang-Undangan . Undang-undang Nomor 12 Tahun 2011 tentang Pembentukan Peraturan PerundangUndangan.

Undang-Undang Nomor 32 Tahun 2004 tentang Pemerintahan Daerah.

Peraturan Pemerintah No. 32 Tahun 2004 tentang Pedoman Satuan Polisi Pamong Praja.

Peraturan Daerah Kabupaten Sleman Nomor 1 Tahun 2011 tentang Pajak Hotel.

Peraturan Daerah Kabupaten Sleman Nomor 9 Tahun 2007 tentang Pemondokan.

\section{Sumber Internet}

Latief, "Jogja Kota Pelajar dan Budaya" http://www.kompasiana.com/latiefm nc/jogja-kota-pelajar-dan-budaya 55094eba813311eb01b1e174

Anonim, "Portal Kost Eksklusif Nomor 1 di Indonesia"

http://kosteksklusif.com/apa-itukost-eksklusif/ di akses pada hari Jum'at 11 Desember 2021 pukul 13 : 25 WIB

Wardhana Endra, "Raksasa Lain dari Jogja" http://www.kompasiana.com/wardha nahendra/raksasa-lain-dari-jogjarumahkosmewah_552e2eaf6ea8349d178b4 $\underline{5 \mathrm{~d} 0}$ diakses pada ahari Jum'at 09 Desember 2016 pukul 20.20 WIB Redaksi "Jogja Student" http://jogjastudent.com/cowokcewek-bebas-nyampur-di-kos-kosanbabarsari/ Di akses pada 14 Desember 2016 Pukul 22:55 http://ejournal.uajy.ac.id/4157/3/2MI H01327.pdf diakses pada hari Minggu 18 Desember 2016 WIB. http://ejournal.uajy.ac.id/4157/3/2MI H01327.pdf diakses pada hari Minggu 18 Desember 2016 WIB.
http://idr.iainantasari.ac.id/5026/6/B AB\%20III.pdf diakses pada hari Minggu 18 Desember 2016 pukul 13.24 WIB. Dikutip dari Lili Rasjidi dan Ira Thania Rasjidi,Dasar-Dasar Filsafat dan Teori Hukum, (Bandung:Penerbit PT Citra AdityaBakti, 2007), hal. 66-67. 